\title{
Influence of organisational and legal changes in the Municipal Sports and Recreation Centre on the effectiveness of provided services
}

\section{Dopad organizačno-právnych zmien v Mestskom stredisku športu a rekreácie na efektívnost’ poskytovaných služieb}

\section{Wojciech Sońta}

Abstract: The article is focused on a research hypothesis that local governments should join the restructuration programs of municipal companies more actively, because their slowly changing way of management does not d allow them to be efficient enough, and at the same time, cheaper and competitive. Privatization is one of the restructuration methods recommended by the local governments which already have implemented it. These are the actions which many local governments needlessly refrain and postpone them in the time being, being afraid of the size and scale of the changes in a company after their implementation. Local communities lose on such proceeding as they are forced to use expensive low-quality services. The purpose of the article is evaluation whether the change of organisational and legal form from a budget unit to a limited liability company is effective. There will be used analysis of literature and source data concerning the Municipal Sports and Recreation Centre limited liability company in Radom to find a solution to the raised research problem. The results of the research were summarized in points from 1 to 9, which proves that the research goal in the article introduction has been achieved.

Key words: Budget unit. Municipal company. Restructuration. Privatization. Services

JEL Classification: P43. R53.

\section{Introduction}

Let us quote what some contemporary researchers of services included in the literature of the subject. Thus, Lange (1967) thinks that services are activities related to satisfying of human needs and they do not serve to satisfy direct production of materials goods. However, Queen (1988) presents quite an original definition, namely that services are 'a subject of exchange between people which cannot be dropped on someone's feet'. While Kotler in his work 
'Marketing' (1994) writes that a service is any action which one part can offer to another, it is intangible and does not lead to any property. Finally, Chmielewski (2001) claims that services are the third emerging sector of business activity whose aim is to satisfy growing material and non-material needs.

In summary, it can be generally stated that the term service originates from economic theories and means all useful activities related to non-productive work in contrast to the activities leading to production of material goods. Taking into account the non-material nature of social services, it is worth to separate a service from the material tool of its provision (for example, swimming pool and swimming, tennis court and playing tennis, football pitch and playing a match on it). The distinction presents two essential levels of provision and consumption of services

- level of service infrastructure analysis,

- level of service satisfaction.

However, classical theorists coming from the property school claim that public property of a land (or other permanent resource) inevitably means dispersion of responsibility and lack of constant aspiration to its smart using, taking care of it and keeping for further users. Aristotle, among other things, wrote about it: 'the more people are entitled to something, the less effort it can count on', that it becomes a team property Aristoteles (2006). It can be confirmed by observations regarding the use of communities which are devastated, overexploited, because they can be used for free. The opinion can be confirmed by the experiences of the local government authorities with parks and recreational devices (Hardin, 1968).

In the 1980s, a new public management concept appeared in the western literature (New public management - NPM), which was a kind of managerial revolution in the public economy. The model is aimed to release the public sector initiative by using funds from the private sector (Grzymała, 2010). The new public management in a commune is reflected in the managerial management model in which the NPM instruments can be used, for example the communal property privatization, contracting services outside or public-private partnership. The model is based on the formula which brings benefits. It can be expressed by the equation: Privatization + Market + Competition $=$ Efficiency + High Quality (Grzymała, 2010, p. 174)

In relation to the above mentioned, local governments should become more involved in restructuring programs of municipal enterprises. There are still too few changes realized which would allow to manage municipal enterprises in a more effective, cheaper and more competitive way. One of the restructuring methods is privatization, which was encouraged by the Treasure Ministry and experts, and already implemented by local governments. There are actions which 
many local governments needlessly defend themselves and postpone, being afraid of the extent and scale of the change in an enterprise after its implementation. Municipal enterprises are often unprofitable and require investments. Mainly, local communities, which are forced to use expensive services with low quality, lose on it.

The aim of the article is to estimate whether the change of the organizational and legal form of the entity from a budget unit to a limited liability company is rational and effective. Perhaps, it is according to the classical principle of economics, where it is claimed that actions will be rational if there is a maximizing effect of the given expenses. To find a solution to the research problem, we have used analysis of literature studies and source data concerning the Municipal Sports and Recreation Centre limited liability company in Radom, hereinafter referred MSaRC. The community of Radom has $100 \%$ shares in the company, which provides physical education and tourism services and creates conditions for organization and development of sport.

\section{Specifics of communal services provision - theoretical approach}

Local communities make efforts to create a friendly community of their inhabitants who would be able to take care about themselves. This is usually reflected in the prices and quality of the provided communal services, which affect the standard of living. This is a purpose of competition which leads to lowering prices and favours increasing services quality. The changes in the municipal economy sector should bring market mechanics to this area. It is necessary, because most communal companies, although they act in the situation of natural monopoly, also must take care of costs reduction and solicit customer satisfaction. The initiator (the commune), the consumer (the local community) and the manufacturer (MSaRC) are connected by some streams: reporting demand, delivering services and payments. The relations between the three participants of the services are presented in figure 1 .

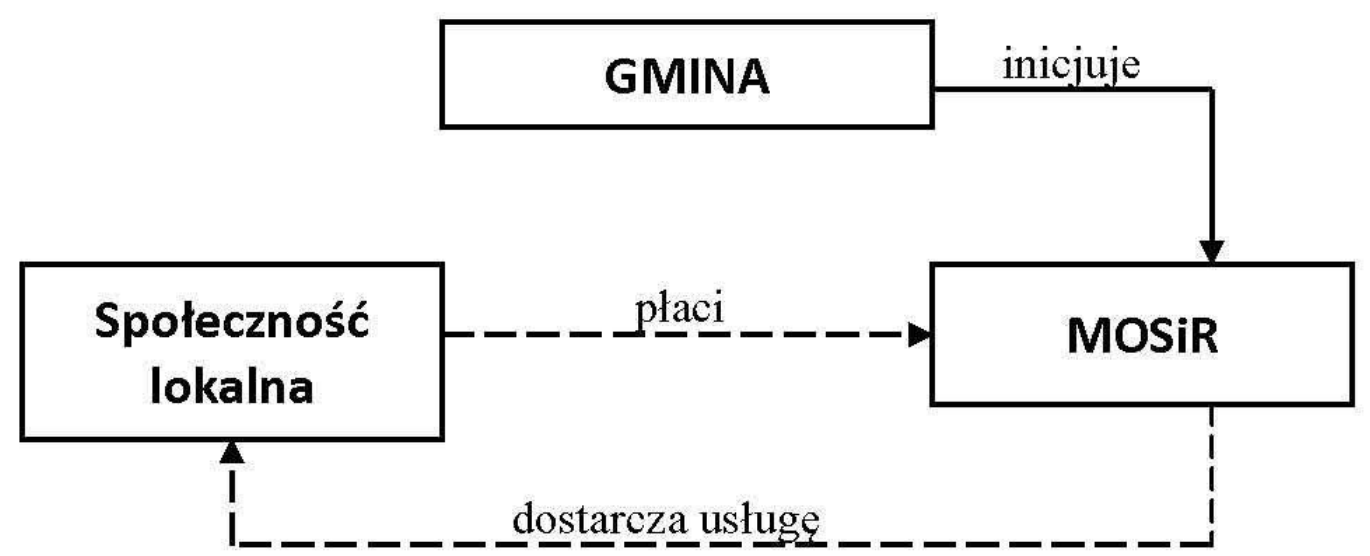

Figure 1 Relations between the initiator of services, the local community and the manufacturer Source: Own study based on Savas (1992, p. 71) 
The municipal sector is a specific area of economic activity. The existence of expensive infrastructure, often created by all residents of the commune, does not allow the services to stand the fierce competition. The community authorities providing the services through their own business entities find themselves in a dual role - as an entrepreneur who should be oriented towards profit maximization, and as a representative of the local community interests; therefore, they must take care of a competitive price and good quality.

Separation of the entrepreneur role from the market regulator role is a solution of the situation. The community should not run a business activity, but only focus on being an initiator (regulator), making sure that the procedures and services quality, which are interests of their residents, are followed. The municipal economy includes mainly tasks of public utility nature whose purpose is continuous and uninterrupted meeting of collective needs of the population through providing commonly available services. The commune is responsible for ensuring adequate services supply, but it does not have to provide them by themselves.

According to the constitutional acts, among others, matters in the field of physical culture and tourism as well as creating of organizational conditions conductive to the development of sport belong to the tasks of communes. In accordance with the municipal economy act, local government bodies can perform their tasks through own organizational units, including companies, or through creating operation conditions for other entities. The choice of the form of municipal services organization is an element of the community policy.

The simplest operation is to appoint a unit or a budget institution in the commune. It also allows keeping a full control over the entities. Decisions in the area have been left to the communities which were searching optimal models by trial-and-error method on its own. The operation through a unit or budget institution should be used exceptionally and only to a certain extent. The formula mentioned above is confirmed, as it was presented in the literature about small-size units, mainly with non-profit character.

However, it is related to a danger of a difficult situation for families and a large unemployment in the given area, which can cause that the business activity of the local government will convert into a specific form of social help. The formula of a budget institution or a unit would then allow providing of services at lower prices than market ones and compensating of financial shortages in the budget with subsidies from the commune. However, it can distort financial transparency of the company and cause that the unit or the budget institution will not be interested in modernization of the production and reduction of the costs. Due to lack of competition, there will not be any motivation to lower the prices. There will also 
not be any interest to improve its profitability. It is caused by the fact that the budget institution's financial surplus is not located in its fund. Management of the unit cannot allocate itself the funds for investment. In the case of lack of profitability, possible shortages are also covered from the commune resources. It is also much harder to take a decision about employment rationalization.

However, the municipal companies operating on the basis of commercial law have a more efficient modernization of public utility services. They also enable establishing

partnerships between the communes and acquiring external investors. At the same time, with such a solution, the local government does not lose control over the company's operation.

As it appears from the above mentioned, companies can play a significant and effective role in the commune activity. Their advantage is, first of all, a flexible form of organizing business activity, including also communal, by partners, and in the case of a sole proprietorship, by its founder, it means the commune (Brol, 1993, p. 53).

The next step after transformation into a company is the decision to find an investor and sell part of its shares. The package of shares to sell usually does not exceed $49 \%$ of the company value. There are already many cases in Poland when the local government decided to sell part of the existing municipal companies. An advantage of the solution is acquiring of know-how from an ordinary foreign investor specialized in a given field and also funds for future investment (Žárska, Kozovský, 2007).

Public utilities are characterized by a high share of fixed costs, which reduces the possibility to lower the price. On the other hand, they operate in a stable demand environment, which allows them to use long-term planning and make investment. Providing public utility services through companies established by the communes brings a more effective and rational use of their property. In comparison to budget institutions, the employment efficiency in commercial law companies is much higher. In municipal enterprises work efficiency is mainly determined by factors which are independent of

an employee under the influence of implementation of mechanization and automation in many activities, and in comparison with other fields, the efficiency in municipal enterprises is much lower. Hence, it has a limited cognitive value because it is mostly determined by the demand variability (Bachor, 2009). In relation to the above mentioned, there arises a question whether transformation of the units and budget institutions into commercial law companies is a future of the municipal sector. 


\section{Organizational and legal changes in $1990-2019$}

In relation to the time censorship during the considered period from 27th May 1990 (the moment of the local government reactivation in Poland) till 3rd June 1997, which is the date determined by the municipal economy act ordering the local governments by the power of law to transform municipal enterprises applying the regulations concerning state enterprises into commune companies. The changes mainly concerned the municipal enterprises which did not carry out the transformation by themselves by 30th June 1994 in spite of the obligation to do so (The regulations putting into practice the territorial local government act,1990). However, it is necessary to notice that there were companies which previously felt the need of transformation and they realized it, e.g. The Municipal Communication Companies, The Municipal Waterworks Companies, etc.

The second period, it means from 1st July 1997 till now, includes changes of the organization and legal form of providing municipal services and type of restructuring, which belongs to the competences of TLGUs (territorial local government units), however participation of the state in the process seems to be advisable, especially in terms of co-creation of formal and legal, economic, educational or research environment. It is justified by a specific contradiction which appears in providing municipal services by TLGUs, because the TLGU has a double role here, as the owner of the enterprises, and at the same time as a representative of local society interests. In order to overcome the contradiction, it is necessary to implement market mechanisms to the municipal economy, inter alia through ownership transformation, mainly commercialization and privatization of the municipal entities. The extent of transformation seems to be insufficient, as in 2014, in the examined group of 1475 budget institutions, there were:

Equations and formulae should be typed and numbered consecutively with Arabic numerals in parentheses on the right hand side of the page (if referred to explicitly in the text).

- created 5 new budget institutions;

- created 4 budget institutions after transformation of the budget units;

- transformed 1 budget institution into limited liability company;

- liquidated 2 budget institutions (Information about the transformations, 2014)

The functioning economic entities can be categorized from different points of view and for different purposes. One of the criteria is the method of counting (connections) with the budget. From this point of view the organizational units are divided into units connected with the budget by gross and net method. 


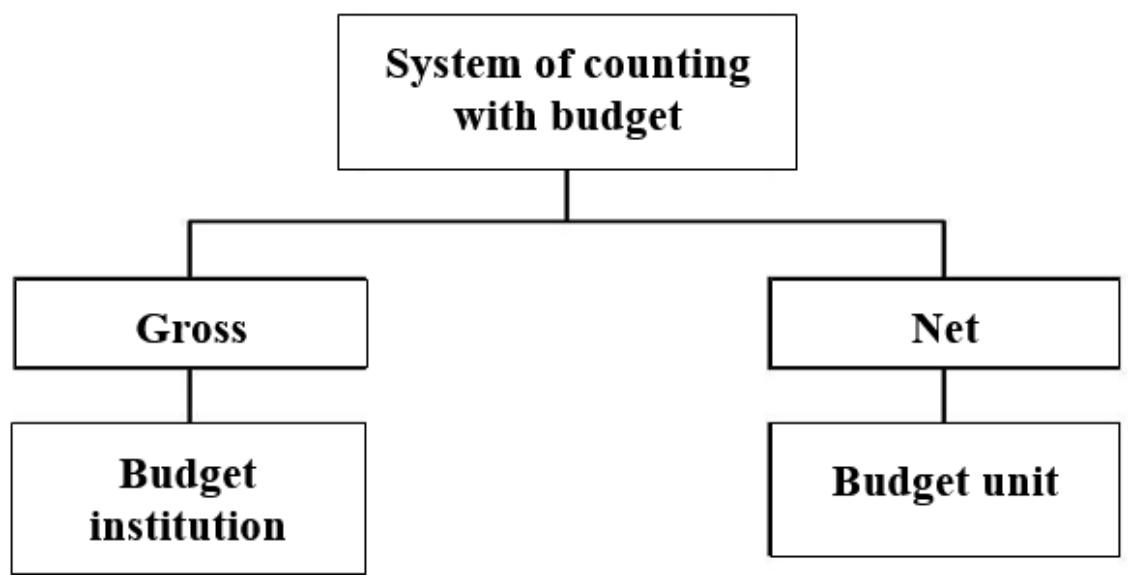

Figure 2 The system of counting with the institution's budget and the budget unit Source: Own study based on the Public finance act from 2009.

The system of net connections is divided into two types. The first is more typical and it relies on including to it the general difference between the sums of incomes from sales and the sums of expenses to maintain a given unit. In the case of keeping a positive result, the enterprise makes payments to the budget, in the opposite case, which means a negative result, the enterprise can get a budget subsidy. Sometimes instead of a simple solution, the connection system with the budget can be more complex, namely there are several balances included in the budget economy resulting from compensation of the sums of a different kind of income and expense. It should be noted that within the net system some special resources functioned till 30th June 2005, but they did not matter too much.

The gross system is the second method of connections of the entities with the budget (full amount of the incomes and expenses). It can be applied in relation to the budget institutions.

A characteristic feature of the units is that their expenses are covered by the budget; it means they are budget expenses. The incomes they earn are fully paid to the budget i.e., they are budget incomes. Therefore, it can be said that the budget institutions only administer incomes of a given budget institution. The method of the entities and budget connections means that the whole sum of each income and each expense is a component part of the budget economy.

The main purpose of the public finance act of 27th August 2009 was to improve the public finances, among other ways by limitation of organizational and legal forms of the sector, and also to strengthen the regulation norms in the TLGU budgets. Based on the new act, as it was mentioned the auxiliary forms were liquidated and the scope of activities of the budget units limited to a specific catalogue of the own tasks (Sońta, 2010). The transformation procedures in the capital companies differ fundamentally from the procedures in the entities of the local 
government sector, in terms of legal, organizational and legal regulations. They are focused on the fact that the newly created entities are more effective in their activity and at the same time, the risk related to their future functioning is excluded. In the study concerning the privatization pilot program in 150 municipal enterprises, it was claimed that a majority of municipal enterprises after the change of their organizational and legal form, mainly from a unit or a budget unit into a commercial law company, improved their profitability (Majewski, 2005).

The essence of the merging procedure lies in the fact that two separate economic structures and wealth masses create one entity - an acquiring company or a newly established company.

\section{Effectiveness of providing services after the transformation of the Municipal Sports and Recreation Center (MSaRC) into a company}

The entities providing goods and services subordinated to the local government should operate according to the principles of efficiency and effectiveness, which are often marginalized in practice (Szołno, 2016). The public finance act in its content repeatedly stresses the importance of efficiency and effectiveness in the public sector entities in terms of functioning and spending of the public funds "with respecting the rules of obtaining the best results from the given expenditures and optimal selection of methods and means aimed to achieve the set aims' (Ustawa, 2009).

The effectiveness of spending the public funds should be considered as searching for savings in terms of application of the solutions which will maximize the effects (Matwiejczuk, 2006). However, the savings should not be perceived as a mechanical reduction of the expenses and desisting from performing of some public tasks, but as spending of resources in such a way as to bring the greatest benefits. The effectiveness depends on achieving the set aims having the best ration of the incurred costs to the achieved results, hence the classic input-effect relation (Kachniarz, 2012). On the other hand, the effectiveness means achieving the set aims, which somehow marginalizes the cost side. In the public finance sector, the effectiveness should refer to direct aims, tasks and activities. Management of the effectiveness is based on monitoring of the relation between the costs and the achieved results. Precise and ongoing monitoring becomes a chance to obtain satisfactory results in performing the entrusted tasks.

An instrument which allows to test the effectiveness and efficiency of the operations are measures whose usefulness depends on correction of their selection. Properly selected measures allow for a constructive assessment of a unit functioning and, as a consequence, an increase in the efficiency of the incurred expenses. The measures provide information both about the extent to which the aims have been achieved and the costs of their achievement, which is a decisive 
factor in the decision-making process. Therefore, it is important to set and formulate the requirements properly. The emphasis on the effectiveness and efficiency resulted in separation of the measures in terms of product, result and impact.

Product related measures reflect completion of a task in a short time horizon. They indicate specific products (i.e., goods and services) obtained in the process of performing the tasks. Their purpose is to evaluate the achieved results (e.g., number of complaints about the provided services, or sales value).

On the other hand, result related measures measure direct effects of the tasks completion, also in a short time horizon (e.g., monthly number of working hours, or employment level).

Impact related measures describe long-term effects. They measure long-term consequences of actions (Lubińska et al., 2011); therefore, they are the most difficult to construct, because the risk problem should be assessed in them (e.g., surveying opinions of users of the goods and services, safety of the provided services).

The Municipal Sports and Recreation Centre limited liability company in Radom was established in 2004 as a result of liquidation of the budget institution with the same name. Sport facilities of the MSaRC are: Orka, Delfin and Aquapark Neptun swimming pools; playground with artificial surface; athletics and football stadium; sports hall; Borki recreation centre; artificial ice rink. As it results from the above, it is a significant property whose assets reach 85 million PLN. Moreover, the MSaRC has many investments, and among them, construction of a football stadium at the Struga street for 15 thousand spectators, or the City Bike program for the residents of Radom since April 2017.

The entities using the services provided by the MSaRC were divided into four categories. They are:

- organizational units of the City Radom commune conducting sports trainings (e.g., physical education, sports classes), non-governmental organizations with public benefit activities and volunteering,

- non-governmental organizations conducting activities in the field of dissemination of physical culture,

- other non-governmental organizations including sports clubs which do not run a business, - individuals.

Charging fees for the public services provided by the MSaRC is regulated in its statute, which specifies the type of object and the price (Directive no. 1165/2016 of the President of the 
Radom City). There price list gives the information about the duration of the provided services -45 and 60 minutes - and about the prices. The services provided until 4 p.m. are cheaper and after 4 p.m. the prices are higher. The type of the service has also an influence on the price. Finally, the price also depends on the day - the rates of services are different on weekdays, Saturdays, Sundays or holidays. From the above mentioned it follows that the main factors affecting the price are the demand for the service in a given time and the standard of the provided services. It is worth to add those children up to 3 years use the services free of charge, while students, schoolchildren, disabled people, pensioners and retired people pay a reduced price.

In the following part we will focus on the evaluation of the effectiveness of the provided services after the transformation of the MSaRC into a company. The operational efficiency measures of the MSaRC functioning were presented in Table 1. We evaluated the effectiveness and verified a research hypothesis based on them that the change of the organizational and legal form from a budget unit into a limited liability company has improved the functioning of the MSaRC

The research sample consisted of 30 employees of the audited company and of the supervisory body of the City Hall of Radom. There were people who were well informed regarding the studied issue. The sample included employees working in the two organizations before and after the performed changes. The study covered a period of

6 years, i.e. from 2014 (the year of transformation of the budget unit into the limited liability company) till 2019. The year 2020 was excluded from the research due to the financial turbulence related to the pandemic that changed the conditions of the company functioning.

The scale of the evaluation was set from -2 to +2 of each criterion included in the table 1 . Next, the number of the obtained points from the survey was multiplied by a criterion factor included in the description under the table. Moreover, in the 'no-change' column there was given in brackets the number of respondents who chose such evaluation. The number is surprisingly high, reaching 164 people. Taking into account the too short period of the company's functioning in the new organizational and legal form, such a phenomenon should be considered as normal. 
Table 1 Evaluation of the effectiveness of the provided services of the MSaRC after the transformation into a company

\begin{tabular}{|c|l|c|c|c|c|c|}
\hline No. & \multicolumn{1}{|c|}{ Evaluation in the range } & (n) & (n) & & & \\
\hline+1 & Sales increase & +20 & +8 & $0(4)$ & -6 & -4 \\
\hline 2 & Increase in profitability & & +5 & $0(10)$ & -10 & -10 \\
\hline 3 & Decrease of costs & & & $0(15)$ & -10 & -10 \\
\hline 4 & Improved flow & & +10 & $0(10)$ & -5 & -10 \\
\hline 5 & Increase in investment expenditures & +30 & +15 & 0 & & \\
\hline 6 & Improvement of the services' quality & +10 & +15 & $0(5)$ & -5 & \\
\hline 7 & $\begin{array}{l}\text { Improvement of profitability index } \\
\text { of the equity capital }\end{array}$ & +40 & +5 & $0(5)$ & & \\
\hline 8 & $\begin{array}{l}\text { Improvement of management's } \\
\text { effectiveness }\end{array}$ & +20 & +10 & $0(10)$ & & \\
\hline 9 & Better relations with the commune & +20 & +10 & $0(10)$ & & \\
\hline 10 & Employment growth & & +5 & $0(25)$ & & \\
\hline 11 & Increase of employees' wages & & +5 & $0(25)$ & & \\
\hline 12 & Increase of fees' tariff & & & $0(25)$ & -5 & \\
\hline 13 & Safety of the services' provision & & +5 & $0(20)$ & -5 & \\
\hline 14 & Total & +120 & +93 & $0(164)$ & -46 & -34 \\
\hline
\end{tabular}

Description: much better +2 , little better +1 , without changes 0 , it is worse -1 , much worse -2 . Source: Own survey

After the transformation of the MSaRC into a limited liability company, the evaluation of its performance on the basis of economic and financial indexes showed that the sales increased, but not the profitability. It is also worse in terms of the cost reduction. However, the situation in terms of quality of the provided services slightly improved. There was also a slight improvement of the company financial solvency. The situation is much better in investment expenditures, which increased due to a good access to financial resources (bank loans, leasing, aid funds from the UE). The significant improvement of the profitability index of the equity capital deserves attention. During the considered period, both the wages as well the employment level remained unchanged. There was observed a slight increase in the wages among the leastpaid people, which was related to legal regulations concerning the minimum wage.

The effectiveness of the company management also improved, which resulted in better relations with the commune. Another point is the level of tariffs. The budgetary institution did not have to charge depreciation, so the tariffs were relatively lower in comparison with the ones agreed by the MSaRC. On the one hand, there is assumed that the enterprises should be profitable, on the other hand, they realize a social mission to meet basic and necessary needs. They should not strive to maximize the profits, which would be quite easy to implement in a 
monopolistic position on the local market. Reconciliation of the economic function with the social one would not allow to automatically apply the market prices (Sadowy, 2010).

It must be noted that the MSaRC was not a dominant company on the Radom market in the field of the swimming pool and artificial ice rink services and it had a competitor commercial company operating on the Slonecza Housing Estate. The swimming pool was put in service recently, so the standard of its equipment is more modern and thus the provided services are diversified and at a higher level. In the initial period of its functioning, the fees were comparable with those of the municipal company in order to attract customers and later, when they had enough customers, the prices were increased. It is necessary to note that the swimming pool is located in the city centre close to the Slonecza Housing Estate and it has a large parking as well convenient access by public transport, which is an additional advantage influencing the use of its services.

The survey conducted according to age groups in different sports facilitates of the MSaRC included 100 people of the local community ${ }^{1}$. The respondents could choose more than one possibility; hence the sum of the points can be more than the surveyed population in the given age group.

Table 2 People who used the services of the MSaRC by age.

\begin{tabular}{|c|c|c|c|c|}
\hline Age & Mass events* & Swimming pool & Water Sports & Winter Sports \\
\hline $\mathbf{0}-\mathbf{1 7}$ & 25 & 25 & 16 & 14 \\
\hline $\mathbf{1 8}-\mathbf{3 0}$ & 35 & 20 & 10 & 15 \\
\hline $\mathbf{3 1} \mathbf{- 5 0}$ & 20 & 22 & 5 & 6 \\
\hline $\mathbf{5 0}+$ & 15 & 15 & 2 & 3 \\
\hline
\end{tabular}

* matches and sports competitions

Source: Own survey.

The survey showed that all age groups had the greatest interest in mass events and then in the swimming pool. Water and winter sports had a similar interest among the age groups because they are sports which can be played in summer or winter season. The times when swimming pools were built outdoor and they were used only in summer season are the past now. The motives why the respondents used the services are willingness to spend free time actively, which was declared by $50 \%$ of the surveyed people, improvement of physical fitness $30 \%$, promotion of attitudes to improve health $20 \%$ (especially in the age group 50+). Disabled people with their handicaps were also included among the respondents, which should be considered as a positive phenomenon, because it prevents their social exclusion. Analysis of

\footnotetext{
${ }^{1}$ The survey was conducted by students of the UTH in Radom as a part of physical education subject
} 
the effectiveness of the services provided by the MSaRC after its transformation into a company is presented in Table 3.

Table 3 Evaluation of the effectiveness of the services provided by the MSaRC after the transformation into a company by the recipients

\begin{tabular}{|c|c|c|c|c|c|}
\hline Evaluation scale & Much better & $\begin{array}{c}\text { Little } \\
\text { better }\end{array}$ & $\begin{array}{c}\text { Without } \\
\text { changes }\end{array}$ & It is worse & $\begin{array}{c}\text { Much } \\
\text { worse }\end{array}$ \\
\hline $\begin{array}{c}\text { Quality of } \\
\text { services }\end{array}$ & +58 & +30 & $0(20)$ & -15 & -12 \\
\hline Tariff & +70 & +20 & $0(23)$ & -12 & -20 \\
\hline Safety & +78 & +25 & $0(22)$ & -10 & -8 \\
\hline Total & +206 & +75 & $0(65)$ & -37 & -40 \\
\hline
\end{tabular}

Description: much better +2 , little better +1 , without changes 0 , it is worse -1 , much worse 2.

Source: Own survey

The analysis shows that the quality of the services increased, but there was also observed an increase in the tariffs. There are also people who are sceptical about this fact. Referring to the safety in the stadiums and swimming pools, the evaluation was positive. However, after one of the lost football matches by Radomiak a group of hooligans invaded a nearby Lesniczowka park and there they released their negative emotions by destroying benches, overturning waste bins, breaking young trees. It was hard to believe that heavy concrete bins were scattered all over the park. It happened because the police were protecting the streets while the park was unsecured. It should be noted that the occurrence was incidental, because since then four years passed and there were not observed any similar situations.

An important aspect for the MSaRC is the fact that the company conducts a lot of investments and therefore it has a status of an internal entity authorized to provide public services that can neglect a tender procedure, which is an important factor. The case was a subject of the NSA judgement (Act signature II GSK 105/05, 2005). Moreover, according to the jurisdiction of the European Court an internal entity must meet the following criteria:

- from the formal point of view, it is a different legal unit than the purchaser,

- in relation to the unit, the purchaser performs control permissions, like in its own organizational units,

- the entity performs a significant part of its activity instead the purchaser.

The test of verifiability whether the MSaRC is an internal entity requires answers to the above questions.

- the MSaRC is a separate legal unit in relation to the Radom Commune stakeholder, 
- - the Radom Commune stakeholder performs control permissions in relation to the company, which is based on the defined statute, by unanimous resolutions in the most strategic decisions regarding the company operation,

- the MSaRC will perform activities for the Radom Commune, which will be ordering tasks according to its needs.

The answers to all the premises are affirmative and therefore there is no doubt the MSaRC is an internal entity.

The fact of entrusting the own task will allow the Radom Commune to perform an effective control of the way of the own task's realization what is a matter of fundamental importance for the city and its residents. This is a way to ensure a high quality of services which are focused on social, rather than commercial purposes. In the case of entrusting a commitment to provide services for the internal entity, the price which the Radom Commune pays for the services is only a reflection of the costs incurred by the company, including a reasonable profit allowing the company to maintain an appropriate quality standard of its facilities. The reasonable profit, understood as a return of capital which is considered as normal in a given member country, has not been defined in a rigid way. The amount up to $6 \%$ was a proposal of the Ministry of Regional Development in the area of financing from operational programs of the entities that are obliged to provide services (version of 16th January 2009).

A detailed regulation of the conditions for the company to perform an entrusted task and the mechanism of financial calculation between the Radom Commune and the company are a subject of arrangements made on the basis and within limits resulting from the execution contract.

Table 4 Advantages and disadvantages of the MSaRC functioning as an internal entity

\begin{tabular}{|l|l|}
\hline \multicolumn{1}{|c|}{ ADVANTAGES } & \multicolumn{1}{c|}{ DISADVANTAGES } \\
\hline - quick and easy realization of the services & - no pressure from competitors \\
- favourable condition of the services' & - lack of motivation from the MSaRC \\
realization & - lack of rationalization on the expenses' \\
- saving time & side \\
- possibility of focusing the communes on & - greater supervision from the commune's \\
other tasks & side \\
\hline
\end{tabular}

Source: Based on the research by the MSaRC limited liability company in Radom

Everybody should be aware that the advantages and disadvantages of the internal entity functioning can be considered from the company and the owner point of view as well as the recipient of the service point of view, which means consumer. Therefore, the formulated advantages and disadvantages can be debatable - it means that what is an advantage for one 
side can be a disadvantage for the other side. It was proved based on the results of the survey included in the tables 1,2 and 3.

\section{Summary}

The analysis has shown that the changing legal regulations, which were targeted on more effective forms at the given time, had an influence on the organizational and legal changes in the MSaRC. In the studied period there was observed changes starting from the municipal enterprise functioning on the basis of the regulations of the state enterprises act to the commercial law companies. The situation has changed after Poland joined the EU. The public aid which is prohibited as a rule to EU member states according to the act 107 paragraph 1 of the Treaty about functioning of the EU, the C 326/49, 2012 Official Journal of the European Union also in relation to the municipal sector, which is an essential element of proceeding of the competition on the market, was limited. There was implemented a new form of internal entity for the transitional period. Whether the time will be properly utilized by the municipal enterprises and local governments, will be shown in the future.

The arguments for the creation of the M.S.a R.C. limited liability company to manage sports and recreation facilities in comparison to the communal budget institution are:

1. Running a business in the form of a company increases the autonomy of the unit and motives to search additional possibilities on the market

2. Management of the company as 'on its own' and it is interested in reduction of the costs, because the savings effects remain in the enterprise and they are not transferred to the commune account as it is in the case of the communal budget institution.

3. Possibility of extending the scope of activities outside the commune and beyond the range of public utility, at the same time maintaining the rules of providing the sports facilities to the commune's residents.

4. Possession of legal person thanks to which it has possibility to individually gain capital, for example taking loans, leasing, entering into a public-law partnership or applying for aid funds; the budget institution is not a legal person, which causes that in a certain sense it is an 'invalid' economic entity.

5. Separation of the obligations resulting from the company operation beyond the communal budget does not increase the general budget debt.

6. The company offers opportunities of independent investment (among others in the building of a sports and entertainment hall). 
7. Quicker responding to the customers' needs due to the independence in the management of the company resources.

8. Possibility to calculate depreciation.

9. Possibility of further VAT deduction, which is in the current legal status impossible.

It was claimed that the NPM tools like contracting services, leasing of property, managerial contract agreement are not much used by the company. One of the results of the transformation of the budgetary institution into a company was an improvement in the effectiveness of some economic and financial indicators. An important matter in the management of the municipal company is a skilful connection of social problems with the financial performance criteria. The factors affecting the model of the company management are size of the city, territorial range of provided services and quality of staff. Some researchers in this field claim that there is not one best universal model of management of a municipal company Grzymała (2010). However, the commune should remain a unit controlling municipal activities on its area independently of the accepted model. The presented evaluation of the efficiency is a general nature. It was carried out on a small sample of respondents and therefore it will require further in-depth research.

The current pandemic situation does not have a positive effect on the changes which were made in the municipal sector in the years prior to 2020. As a result of the lockdown, there was a significant decrease of provided services and thereby revenues. Some of the budgetary financial resources in 2020 were moved to the fight with the coronavirus. For this purpose, the city resigns, among other things, from running of the Radom City Bike.

\section{References}

[1] Aristoteles. (2006). Polityka [ Politics]. Preklad Piotrowicz 1, Szymański, M. Warszawa, PL: Wydawnictwo PWN.

[2] Bachor, W. (2009). Efektywność majątku trwatego w spółkach komunalnych [The effectiveness of fixed assets in municipal companies]. Warszawa, PL: Szkoła Główna Handlowa w Warszawie.

[3] Brol, J. (1993). Formy organizacyjno-prawne działalności komunalnej i gospodarczej gminy, [w.] Przekształcenia w gospodarce komunalnej [Organizational and legal forms of communal and economic activity of the commune, [w.] Transformations in the communal economy]. Zielona Góra, PL: Zachodnie Centrum Organizacji w Zielonej Górze. 
[4] Chmielewski, J. (2001). System planowania przestrzennego harmonizującego przyrodę i gospodarkę [A system of spatial planning harmonizing nature and economy]. Lublin, PL: Politechnika Lubelska.

[5] Grzymała, Z. (2010). Prywatyzacja sektora komunalnego w Polsce Aspekty organizacyjnoprawne $i$ ekonomiczne [Privatization of the municipal sector in Poland Organizational, legal and economic aspects]. Warszawa, PL: Oficyna Wydawnicza SGH w Warszawie

[6] Hardin, G. (1968). The Tragedy of the Commons. Science, 162(3859), 1243-1248. Doi: 10.1126/science.162.3859.1243

[7] Informacja o przekształceniach i prywatyzacji mienia komunalnego w 2014 r. MSP Warszawa [Information on the transformation and privatization of municipal property in 2014. MSP Warszawa]

[8] Kachniarz, M. (2012). Efektywność ustug publicznych - teoria i praktyka [Efficiency of public services - theory and practice]. Wrocław, PL: Wyd. UE we Wrocławiu.

[9] Kotler, P. (1994). Marketing. Warszawa, PL: Gebethner i ska.

[10]Lange, O. (1967). Wstęp do ekonometrii [Introduction to econometrics]. Warszawa , PL: Państwowe Wydawn. Naukowe.

[11]Lubińska, T., Strąk, T., Lozano Platonoff, A., Będzieszak, M., \& Godek, M. (2011). Paradygmat budżetowania zadaniowego [The performance budgeting paradigm]. 6, 50 69. In T. Lubińska (Eds.), A Kierunki modernizacji zarządzania w jednostkach samorzadu terytorialnego [Directions of modernization of management in local government units] (pp. 50-69). Warszawa, PL: Wydawnictwo Difin S.A.

[12] Majewski, J. (2005). Program prywatyzacji podmiotów komunalnych [Program for the privatization of municipal entities]. Gdańsk, PL: Wydawnictwo Gdańskie.

[13] Matwiejczuk, R. (2006). Zarządzanie marketingowo-logistyczne [Marketing and logistics management]. Wartość i efektywność. Warszawa, PL: C.H. Beck.

[14] Przepisy wprowadzające ustawę o samorządzie terytorialnym z dnia 10. 05. 1990 [], Dz. U. $1990 \mathrm{nr}$ 32, poz. 1 ,

[15] Sadowy, M. (2010). Podstawy ekonomiki przedsiębiorstw komunalnych [Fundamentals of economics of municipal enterprises]. Siedlce, PL: Wyższa Szkoła Finansów i Zarządzania w Siedlcach.

[16] Savas, E. S. (1992). Prywatyzacja. Klucz do lepszego rzadzenia [Privatization. The key to better governance]. Warszawa, PL: PWE. 
[17] Sońta, W. (2010). Formy wykorzystania mienia komunalnego [Forms of using communal property]. Radomia, PL: Wyd. Politechniki Radomskiej.

[18] Szołno, O. (2016). Wybrane aspekty pomiaru efektywności i skuteczności jednostek samorządu terytorialnego [Selected aspects of measuring the effectiveness and efficiency of local government units]. Finanse, Rynki Finansowe, Ubezpieczenia, 6(84), 91-99. Doi: 10.18276/fru.2016.84/1-08,

[19] Traktat o funkcjonowaniu UE, Dziennik Urzędowy Unii Europejskiej [Consolidated versions of the Treaty on European Union and the Treaty on the Functioning of the European Union], C 326/49, 2012 r art. 107 ust 1.

[20] Ustawa z 27.08.2009 o finansach publicznych [Act of August 27, 2009 on public finances], Dz. U. 2013, poz. 885, z późn. zm.

[21] Ustawa z 20 grudnia 1996 r. o gospodarce komunalnej [Act of December 20, 1996 on municipal management] Dz. U. $1997 \mathrm{nr}$ 9, poz. 43 ze zm.

[22] Ustawa z dnia 27 sierpnia 2009 r. o finansach publicznych [Act of 27 August 2009 on public finances], Dz. U. 2009 nr 157, poz. 1240 ze zm.

[23] Wyrok Najwyższego Sądu Administracyjnego z 11 sierpnia 2005 r (sygnatura akt II GSK 105/05) odnoszące się do bez przetargowego powierzania zadań publicznych spółkom komunalnym [Judgment of the Supreme Administrative Court of August 11, 2005 (file number II GSK 105/05) relating to entrusting public tasks to municipal companies without a tendering procedure]

[24]Zarządzenie nr 1165/2016 Prezydenta Miasta Radomia z dnia 25 lutego 2016 r. w sprawie zatwierdzenia Regulaminu korzystania z usług publicznych świadczonych przez MOSiR w Radomiu Sp. z o.o. [Regulation No. 1165/2016 of the President of the City of Radom of February 25, 2016 on the approval of the Regulations for the use of public services provided by MOSiR w Radomiu Sp. z o.o.]

[25]Žárska, E., \& Kozovský D. (2008). Teoretické a praktické aspekty fiškálnej decentralizácie [Theoretical and practical aspects of fiscal decentralization]. Bratislava, SK: Vydavatel'stvo Ekonóm. 
Authors' addresses: Associate Professor, Ph.D., K. Pulaski University of Technology and Humanities in Radom, Poland, Faculty of Economics and Finance, Department of Finance and Insurance, e-mail: wojciechsonta@o2.pl 